\title{
Antioxidant activity and ACE-inhibitory of Class II hydrophobin from wild strain Trichoderma reesei
}

DOI:

10.1016/j.ijbiomac.2016.05.068

\section{Document Version}

Accepted author manuscript

Link to publication record in Manchester Research Explorer

\section{Citation for published version (APA):}

Khalesi, M., Jahanbani, R., Riveros-Galan, D., Sheikh-Hassani, V., Sheikh-Zeinoddin, M., Sahihi, M., Winterburn, J., Derdelinckx, G., \& Moosavi-Movahedi, A. A. (2016). Antioxidant activity and ACE-inhibitory of Class II hydrophobin from wild strain Trichoderma reesei. International Journal of Biological Macromolecules. https://doi.org/10.1016/j.ijbiomac.2016.05.068

\section{Published in:}

International Journal of Biological Macromolecules

\section{Citing this paper}

Please note that where the full-text provided on Manchester Research Explorer is the Author Accepted Manuscript or Proof version this may differ from the final Published version. If citing, it is advised that you check and use the publisher's definitive version.

\section{General rights}

Copyright and moral rights for the publications made accessible in the Research Explorer are retained by the authors and/or other copyright owners and it is a condition of accessing publications that users recognise and abide by the legal requirements associated with these rights.

\section{Takedown policy}

If you believe that this document breaches copyright please refer to the University of Manchester's Takedown Procedures [http://man.ac.uk/04Y6Bo] or contact uml.scholarlycommunications@manchester.ac.uk providing relevant details, so we can investigate your claim.

\section{OPEN ACCESS}


Elsevier Editorial System(tm) for

International Journal of Biological Macromolecules

Manuscript Draft

Manuscript Number: IJBIOMAC-D-16-00486R1

Title: Antioxidant activity and ACE-inhibitory of Class II hydrophobin from wild strain Trichoderma reesei

Article Type: Research Paper

Keywords: Hydrophobin; Antioxidant; ACE-inhibitory.

Corresponding Author: Dr. Mohammadreza Khalesi,

Corresponding Author's Institution: Tehran University

First Author: Mohammadreza Khalesi

Order of Authors: Mohammadreza Khalesi; Raheleh Jahanbani, PhD student; David Riveros-Galan, PhD student; Vahid Sheikh-Hassani, PhD student; Mahmoud Sheikh-Zeinoddin, Professor; Mehdi Sahihi, Assistant Professor; James Winterburn, Lecturer; Guy Derdelinckx, Professor; Ali Akbar Moosavi-Movahedi, Professor

Abstract: There are several possible uses of the Class II hydrophobin HFBII in clinical applications. To fully understand and exploit this potential however, the antioxidant activity and ACE-inhibitory potential of this protein need to be better understood and have not been previously reported. In this study, the Class II hydrophobin HFBII was produced by the cultivation of wild type Trichoderma reesei. The crude hydrophobin extract obtained from the fermentation process was purified using reversed-phase liquid chromatography and the identity of the purified HFBII verified by MALDI-TOF (molecular weight: $7.2 \mathrm{kDa}$ ). Subsequently the antioxidant activity of different concentrations of HFBII (0.01-0.40 $\mathrm{mg} / \mathrm{mL}$ ) were determined. The results show that for HFBII concentrations of $0.04 \mathrm{mg} / \mathrm{mL}$ and upwards the protein significantly reduced the presence of ABTS+ radicals in the medium, the IC50 value found to be $0.13 \mathrm{mg} / \mathrm{mL}$. Computational modeling highlighted the role of the amino acid residues located in the conserved and exposed hydrophobic patch on the surface of the HFBII molecule and the interactions with the aromatic rings of ABTS. The ACE-inhibitory effect of HFBII was found to occur from $0.5 \mathrm{mg} / \mathrm{mL}$ and upwards, making the combination of HFBII with strong ACE-inhibitors attractive for use in the healthcare industry. 
Highlights (for review)

\section{Highlights}

$\checkmark$ Production of Class II hydrophobin by wild strain fungi for positive applications.

$\checkmark$ Using of hydrophobin HFBII as a novel protein based antioxidant from fungi.

$\checkmark$ Remarking HFBII as a low ACE inhibitor.

$\checkmark$ Computational modeling for understanding the interactions between HFBII and ABTS. 


\begin{abstract}
There are several possible uses of the Class II hydrophobin HFBII in clinical applications. To fully understand and exploit this potential however, the antioxidant activity and ACE-inhibitory potential of this protein need to be better understood and have not been previously reported. In this study, the Class II hydrophobin HFBII was produced by the cultivation of wild type Trichoderma reesei. The crude hydrophobin extract obtained from the fermentation process was purified using reversed-phase liquid chromatography and the identity of the purified HFBII verified by MALDI-TOF (molecular weight: $7.2 \mathrm{kDa}$ ). Subsequently the antioxidant activity of different concentrations of HFBII $(0.01-0.40 \mathrm{mg} / \mathrm{mL})$ were determined. The results show that for HFBII concentrations of $0.04 \mathrm{mg} / \mathrm{mL}$ and upwards the protein significantly reduced the presence of $\mathrm{ABTS}^{+}$radicals in the medium, the IC50 value found to be $0.13 \mathrm{mg} / \mathrm{mL}$. Computational modeling highlighted the role of the amino acid residues located in the conserved and exposed hydrophobic patch on the surface of the HFBII molecule and the interactions with the aromatic rings of ABTS. The ACE-inhibitory effect of HFBII was found to occur from $0.5 \mathrm{mg} / \mathrm{mL}$ and upwards, making the combination of HFBII with strong ACE-inhibitors attractive for use in the healthcare industry.
\end{abstract}

\title{
Graphical abstract
}

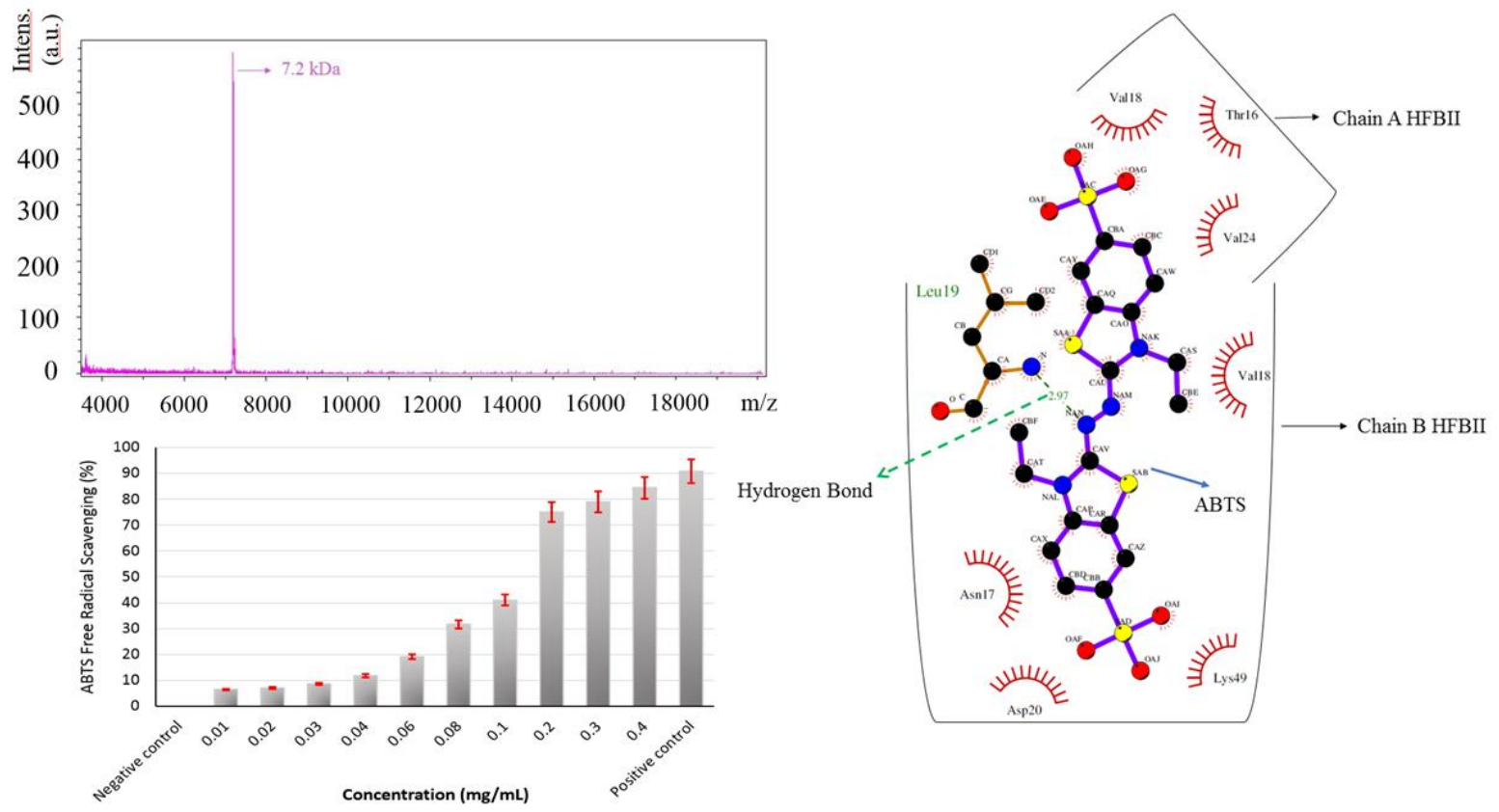




\title{
Antioxidant activity and ACE-inhibitory of Class II hydrophobin from wild strain Trichoderma reesei
}

\author{
Mohammadreza Khalesi ${ }^{a, b^{*}}$, Raheleh Jahanbani ${ }^{a}$, David Riveros-Galan ${ }^{c}$, Vahid \\ Sheikh-Hassani ${ }^{\text {a }}$, Mahmoud Sheikh-Zeinoddin ${ }^{\mathrm{d}}$, Mehdi Sahihi ${ }^{\mathrm{e}}$, \\ James Winterburn ${ }^{\mathrm{f}}$, Guy Derdelinckx ${ }^{\mathrm{c}}$, Ali Akbar Moosavi-Movahedi ${ }^{{ }^{*}}$ \\ ${ }^{a}$ Institute of Biochemistry and Biophysics, University of Tehran, Tehran, Iran \\ ${ }^{\mathrm{b}}$ Department of Food Science and Technology, Shiraz University, Shiraz, Iran \\ ${ }^{\mathrm{c}}$ Centre for Food and Microbial Technology, KU Leuven, Heverlee, Belgium \\ ${ }^{\mathrm{d}}$ Department of Food Science and Technology, Isfahan University of Technology, Isfahan, Iran \\ ${ }^{\mathrm{e}}$ Department of Chemistry, University of Isfahan, Isfahan, Iran \\ ${ }^{\mathrm{f}}$ School of Chemical Engineering and Analytical Science, The University of Manchester, Manchester, \\ UK \\ * Corresponding Authors. Tel: +98-21-66403957 ; Fax: +98-21-66404680 ; \\ E-mail: mkhalesi@shirazu.ac.ir (M. Khalesi) \\ E-mail: moosavi@ut.ac.ir (A.A. Moosavi-Movahedi)
}

\section{Abstract}

There are several possible uses of the Class II hydrophobin HFBII in clinical applications. To fully understand and exploit this potential however, the antioxidant activity and ACEinhibitory potential of this protein need to be better understood and have not been previously reported. In this study, the Class II hydrophobin HFBII was produced by the cultivation of wild type Trichoderma reesei. The crude hydrophobin extract obtained from the fermentation process was purified using reversed-phase liquid chromatography and the identity of the purified HFBII verified by MALDI-TOF (molecular weight: $7.2 \mathrm{kDa}$ ). Subsequently the antioxidant activity of different concentrations of HFBII $(0.01-0.40 \mathrm{mg} / \mathrm{mL})$ were determined. The results show that for HFBII concentrations of $0.04 \mathrm{mg} / \mathrm{mL}$ and upwards the protein significantly reduced the presence of $\mathrm{ABTS}^{+}$radicals in the medium, the IC50 value found to be $0.13 \mathrm{mg} / \mathrm{mL}$. Computational modeling highlighted the role of the amino acid residues located in the conserved and exposed hydrophobic patch on the surface of the HFBII molecule and the interactions with the aromatic rings of ABTS. The ACE-inhibitory effect of HFBII was found to occur from $0.5 \mathrm{mg} / \mathrm{mL}$ and upwards, making the combination of HFBII with strong ACE-inhibitors attractive for use in the healthcare industry.

Keywords: Hydrophobin; Antioxidant; ACE-inhibitory. 


\section{Introduction}

42

Oxidation is an important issue in food science, causing significant chemical and textural deterioration of food products [1]. As a consequence of this phenomenon, free radicals are generated which increase risk factors associated with many hazardous diseases, e.g. different types of cancers [2], cardiovascular disease [3] and Alzheimer's disease [4]. Antioxidants have been reported to lower the risk of such diseases developing [5] with these protective agents being found naturally in many foods consumed by humans and are, sometimes, taken as supplements in the human diet.

Antioxidant activity and ACE (angiotensin I-converting enzyme) inhibitory effects have been noticed together in several studies $[6,7,8]$. ACE is a dipeptidyl carboxypeptidase which inactivates bradykinin (a potent vasodilator) by removal of its carboxyl terminal Phenylalanyl-Arginine dipeptide $[9,10]$. On the other hand, ACE increases the rate of formation of angiotensin II by removing the Histidyl-Leucine dipeptide from angiotensin I. These effects serve to reduce blood pressure, thus prescription of ACE-inhibitors with good oral bioavailability is required $[11,12,13]$. Additionally, it has been observed that ACEinhibitors alleviate the symptoms of type 1 diabetes, hypertension, atherosclerosis, and myocardial infarction [14].

Cultivation of microorganisms for biosynthesis of protein-based compounds as a novel class of antioxidants and/or ACE-inhibitors as alternatives to plant sourced extracts has become a matter of significant interest for biotechnologists and research activity has progressively increased in recent years [15]. There are several reports concerning the use of microbial antioxidants $[16,17,18,19]$, including different microbial extracts and secondary metabolites such as citrinin, protocatechuic, and curvulic acid [20].

Filamentous fungi produce different types of hydrophobins, a family of low molecular weight (MW) proteins consisting four disulfide bridges and a large conserved and exposed hydrophobic patch [21], this structure and the resulting properties conferred to hydrophobins gives these low MW proteins a number of applications in bio-industry [22]. Hydrophobins are split into Class I and Class II, on the basis of their solubility and elasticity of their films $[23,24]$. Class I hydrophobins are rarely soluble in water whereas the proteins from Class II are easily dissolved in the aqueous phase and their films are highly elastic, such that can 
cover and protect lipophilic micelles in a hydrophilic environment $[25,26]$. The large potential of Class II hydrophobins in clinical applications has been described in the literature [27]. Furthermore, Class II hydrophobins have been successfully used for generating the stabilized foams in rich-foam products where control of the air phase is especially important $[28,29,3]$. In contrast, the formation of stabilized $\mathrm{CO}_{2}$ nano-bubbles by Class II hydrophobins have been reported to provoke the gushing phenomenon, and considered to be a negative function of this protein in the carbonated beverages industry [31,32,33].

In drug delivery system adsorption of amphiphilic Class II hydrophobins around the lipophilic micelle-liquid interface results in three special effects: (i) retarding droplet growth, (ii) enhancing the droplet stability, and (iii) increasing the functionality of particles inside the droplet by providing an elastic skin [33]. Velo et al. (2010) [34] report that the Class II hydrophobin HFBII can enhance the stability of itraconazole as a model of a hydrophobic drug. In the same way, researchers used the hydrophobin HFBII from wild strain Trichoderma reesei (T. reesei) to enhance the retention time of ocimene, a non-polar aroma compound derived from hops, in an aqueous phase [35]. Khalesi et al. (2015) concluded that this postponing effect may correspond to the formation of the new stable micelles with certain diameters (mostly in the range of 600-2000 nm), surrounded by HFBII mono- or multi-layer films with a high surface elasticity $\left(0.5 \mathrm{~N} / \mathrm{m}^{2}\right)$ [23]. However, in those studies (i.e. references 34-35) the antioxidant potential of hydrophobins, which may be also the cause of the retention of the volatile compounds, has not been considered.

Therefore, experimental determination of the antioxidant activity of HFBII, supported by the data obtained from computational modeling of the system, as well as measurement of the ACE-inhibitory effect of Class II hydrophobins, as a model of microbial proteins produced by a natural fungus, are presented in this study.

\section{Materials and methods}

\subsection{Microbial culture}

A fermenter (KGW-Isotherm, Schieder $\mathrm{GmbH}$, Germany) with a $1 \mathrm{~L}$ capacity was used for fermentation of $T$. reesei MUCL 44908 (BCCM/MUCL Agro-Industrial Fungi \& Yeast 
Collection, Belgium). The system was equipped with a RW20 digital agitator (IKA GmbH, Germany) and a type R 1389 agitator (PTFE-coated) fitted with a 3-bladed propeller stirrer (Stirrer: $45 \mathrm{~mm}$, Shaft: $8 \mathrm{~mm}$, Shaft length: $350 \mathrm{~mm}$ ). The stirrer was operated in the range $1000-1400 \mathrm{rpm}$, to maintain dissolved oxygen levels. Fermentation was performed at $29^{\circ} \mathrm{C}$ for 7 days with an air flow rate of $1 \mathrm{~L} / \mathrm{min}$. The aqueous medium consisted of peptone $4 \mathrm{~g} / \mathrm{L}$, yeast extract $1 \mathrm{~g} / \mathrm{L}, \mathrm{KH}_{2} \mathrm{PO}_{4} 4 \mathrm{~g} / \mathrm{L},\left(\mathrm{NH}_{4}\right)_{2} \mathrm{SO}_{4} 2.8 \mathrm{~g} / \mathrm{L}, \mathrm{MgSO}_{4} \cdot 7 \mathrm{H}_{2} \mathrm{O} 0.6 \mathrm{~g} / \mathrm{L}, \mathrm{CaCl}_{2} 0.6 \mathrm{~g} / \mathrm{L}$, $\mathrm{CoCl}_{2} \cdot 6 \mathrm{H}_{2} \mathrm{O} 4.0 \mathrm{mg} / \mathrm{L}, \mathrm{MnSO}_{4} \cdot \mathrm{H}_{2} \mathrm{O} 3.2 \mathrm{mg} / \mathrm{L}, \mathrm{ZnSO}_{4} \cdot 7 \mathrm{H}_{2} \mathrm{O} 6.9 \mathrm{mg} / \mathrm{L}$ and $\mathrm{FeSO}_{4} \cdot 7 \mathrm{H}_{2} \mathrm{O} 10.0$ $\mathrm{mg} / \mathrm{L}[36,37]$. For the production of hydrophobin HFBII lactose $(40 \mathrm{~g} / \mathrm{L})$ was added as the carbon source, this is correlated to the biochemical routes of producing HFBII by T. reesei. For further information, see Khalesi et al. 2014 [38] and 2015 [39]. Phosphoric acid was added to maintain a $\mathrm{pH}$ of 4.5-5.0. Inoculation of $1 \mathrm{~L}$ fresh sterilized medium in the fermenter was performed with an overnight culture of $T$. reesei. At the end of fermentation ( 7 days), the medium culture was separated from the mycelium by centrifugation (8000 $g$ for $25 \mathrm{~min}$ at 6 ${ }^{\circ} \mathrm{C}$, Beckman model J2-21, USA) and the supernatant stored at $2{ }^{\circ} \mathrm{C}$ prior to further purification.

\subsection{Protein purification}

HFBII present in the supernatant was purified by reverse phase liquid chromatography, using a Bio-Rad system (Bio-Rad laboratories n.v., Eke, Belgium) and programmed with a Biologic duoflow software. A SOURCE 30RPC column $(25 \times 450 \mathrm{~mm}$, Pall Life Science, Zaventem, Belgium) was installed for the elimination of the impurities. The sample obtained from the fermentation process $(100 \mathrm{~mL})$ was injected to the column. Elution of the proteins was carried out with a linear gradient from $0 \%$ to $60 \%$ acetonitrile (ACN) containing $0.1 \%$ trifluoroacetic acid (TFA). The flow rate was adjusted to $10 \mathrm{~mL} / \mathrm{min}$. Peak elution was monitored by UV detection at $214 \mathrm{~nm}$. Table 1 details the characteristics of the column as well as the experimental conditions used in the purification of hydrophobin HFBII.

\subsection{Identification of hydrophobin HFBII}

Positive identification of the produced hydrophobins was carried out using MALDI-TOF (Brüker Daltonics, GmbH, Germany) in the range of 0-40 kDa MW. The eluted fractions from the chromatography step were collected and dehydrated by vacuum centrifuge (Univapo 150 Ech and Multitrap, Canada). The dried samples were then re-dissolved in $100 \mu \mathrm{L}$ MilliQ 
water with $5 \%$ ACN containing $0.5 \%$ formic acid (FA). To prevent protein aggregation, the samples were vortexed using a bench stirrer $(30 \mathrm{~s}, 1000 \mathrm{rpm})$ and sonicated for $5 \mathrm{~min}$ using an ultrasonic bath (Branson 2510, Wareham, USA). A matrix was prepared by the addition of $10 \mathrm{mg} \alpha$-cyano-4-hydroxy cinnamic acid to $200 \mu \mathrm{L}$ of a solution containing $50 \%$ MilliQ water and $50 \%$ ACN with $0.5 \%$ FA. A $1 \mu \mathrm{L}$ sample was spotted onto a target plate (MTP 384 ground steel, Brüker Daltonics, GmbH, Germany) and mixed with $1 \mu \mathrm{L}$ matrix solution. The fractions which contained only the proteins with the MW of 7.0-7.4 kDa were taken as pure HFBII ( $\kappa$-grade).

\subsection{Measurement of antioxidant activity}

The ABTS $^{+}$[2,2'-azino-bis-(3-ethylbenzthiazoline-6-sulfonicacid)] radical scavenging activity assay is the standard method for measuring the antioxidant activity of different compounds. To perform this analysis, $7 \mathrm{mM}$ ABTS (Sigma-Aldrich, Munich, Germany) solution was oxidized in water by treatment with $2.45 \mathrm{mM}$ potassium persulfate (SigmaAldrich, Munich, Germany), left for 12-16 h in a dark room. This solution exhibited an absorbance of $0.70 \pm 0.05$ at $734 \mathrm{~nm}$ measured by a microplate reader (Biotek powerwave XS2, BioTek Instruments Inc., Vermont, USA) [40,41]. To evaluate the antioxidant activity of Class II hydrophobins, previously produced and purified $\kappa-$ HFBII at concentrations of $0.01,0.02,0.03,0.04,0.06,0.08,0.1,0.2,0.3$ and $0.4 \mathrm{mg} / \mathrm{mL}$ were mixed with $200 \mu \mathrm{L}$ of the prepared $\mathrm{ABTS}^{\circ+}$ solutions. These mixtures were incubated at $25^{\circ} \mathrm{C}$ for $6 \mathrm{~min}$ and the absorbance measured at $734 \mathrm{~nm}$, relative to a blank of $\mathrm{ABTS}^{\circ+}$ solution alone. The positive control used was a mixture of bioactive peptides extracted from Persian walnut with a concentration of $0.05 \mathrm{mg} / \mathrm{mL}$. In the current study, we used the bioactive walnut peptides as a plant-source model of antioxidants, and in the discussion we compare this to a protein from a fungus as a potential microbial antioxidant, i.e. HFBII. These two experiments were run in parallel following the same methodology.

\subsection{Computer-aided molecular modelling}

To identify the possible bindings between the Class II hydrophobin HFBII and ABTS, Molecular Docking was performed using AutoDock 4.2 and AutoDockTools version 1.5.4 using standard parameters. The crystal structure of HFBII in a dimer state was obtained from the protein data bank (PDB code 2B97). The ligand structure was constructed and the energy 


\section{7}

minimized using a PRODRG online server. Images were generated with the PMV and the LigPlot version 4.5.3.

\subsection{Measurement of ACE-inhibitory activity}

The ACE-inhibitory activity of different concentrations of $\kappa$-HFBII from $T$. reesei was determined based on the method described previously by Vermeirssen et al. (2002) [42]. Rabbit lung extract (Sigma-Aldrich, Munich, Germany) as a source of ACE was prepared by dissolving $1 \mathrm{~g}$ of rabbit lung acetone powder in $10 \mathrm{~mL}$ of potassium phosphate buffer (50 $\mathrm{mM}, \mathrm{pH} 8.3)$ containing $5 \%(v / v)$ glycerol. After overnight stirring at $4{ }^{\circ} \mathrm{C}$, the mixture was centrifuged (40000 g, $40 \mathrm{~min}$ ) using an ultracentrifuge (Refrigerated Centrifuge Sigma 3-30k, ATRBiotech Inc. Laurel, MD, USA). The upper phase was collected and stored at $4{ }^{\circ} \mathrm{C}$ prior to analysis. An aliquot $(150 \mu \mathrm{L})$ of furanacrylolyl tripeptide $(1 \mathrm{mM})$ (Sigma-Aldrich, Munich, Germany) was dissolved in $50 \mathrm{mM}$ Tris- $\mathrm{HCl}$ buffer $(\mathrm{pH} \mathrm{8.3)} \mathrm{containing} 0.3 \mathrm{mM}$ $\mathrm{NaCl}$. Different concentrations of $\kappa-\mathrm{HFBII}(0.1,0.2,0.4,0.5$ and $0.6 \mathrm{mg} / \mathrm{mL})$ were then added to the plates. ACE extract was added to each mixture and pre-incubated at $37{ }^{\circ} \mathrm{C}$ for 2 min. A microplate reader (Biotek powerwave XS2, BioTek Instruments Inc., Vermont, USA) was used to record the absorbance at a wavelength $340 \mathrm{~nm}$ before and after a period of 30 min. The negative control was taken to be the sole enzyme and its substrate (N-[3-(2Furyl)acryloyl]-L-phenylalanyl-glycyl-glycine, FAPGG). A mixture of peptide fractions from Persian walnut (purchased from Hamedan, Iran) with MWs lower than $30 \mathrm{kDa}$ was taken as a positive control. This mixture had been previously purified in our laboratory and the ACEinhibitory activity verified. The ACE activity of each sample was calculated based on the following equation [43]:

$$
\text { ACE-inhibition }(\%)=\left(1-\frac{\delta A \text { inhibitor }}{\delta A \text { negative control }}\right) \times 100
$$

where $\delta \mathrm{A}$ inhibitor and $\delta \mathrm{A}$ negative control represent the slopes of the declining in absorbance at $340 \mathrm{~nm}$ for the test and for the negative control samples, respectively.

(1)

8

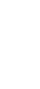


201

202

203

204

205

206

207

208

209

210

211

212

213

214

215

216

217

218

219

220

221

222

223

224

225

226

227

228

229

All experiments were carried out in triplicate. All the data are presented as a mean value \pm standard deviation (SD). The significance of the differences between measured values was determined with a t-test $(\mathrm{P}$ value $<0.05)$ using SPSS version 15.0.

\section{Results and Discussion}

\subsection{Verification of Class II hydrophobin HFBII}

The fermentation process using T. reesei was stopped after 7 days of production, achieving a final biomass concentration of $53.2 \pm 2.7 \mathrm{~g} / \mathrm{L}$. The biomass was discarded after centrifugation and the supernatant used for further analysis. After injection of $100 \mathrm{~mL}$ supernatant phase to the SOURCE 30RPC column, all the fractions of interest, which eluted at ACN 35-50\% $(v / v)$, were collected. An example of the chromatograms generated during the purification step is represented in Fig. 1.

The collected fractions eluted at 35-50\% ACN were submitted to the MALDI-TOF. A MW of $7.2 \mathrm{kDa}$ was obtained in some of the fractions (Fig. 2). These were considered as $\kappa$-grade HFBII (the purest fractions). The obtained HFBII concentration was determined to be $0.20 \pm$ $0.01 \mathrm{mg} / \mathrm{mL}$.

\section{2. $\kappa-H F B I I$ and its antioxidant activity}

The antioxidant activity of different concentrations of $\kappa-\mathrm{HFBII}$ in the range $0.01-0.4 \mathrm{mg} / \mathrm{mL}$ was measured. Although HFBII concentrations below $0.04 \mathrm{mg} / \mathrm{mL}$ were found to have a very small scavenging effect on ABTS radicals, higher concentrations lowered the amount of radicals (Fig. 3). Interestingly, the concentration of $0.04 \mathrm{mg} / \mathrm{mL}$ is equal to the critical micelle concentration (CMC) of HFBII. Thus, our results demonstrate that significant antioxidant activity of HFBII starts at the CMC. Based on the data obtained for different concentrations of $\kappa$-HFBII regarding the antioxidant activity, the IC50 value was determined to be $0.13 \pm 0.02 \mathrm{mg} / \mathrm{mL}$. This value compares favorably with the results for other sources of antioxidants, e.g. crude extract, Albumins, Globulins, Prolamins and Glutelins extracted from 
plant source Adzuki bean seeds with IC50 values equal to $0.65 \pm 0.04,0.89 \pm 0.07,0.54 \pm$ $0.02,0.06 \pm 0.00,1.12 \pm 0.03 \mathrm{mg} / \mathrm{mL}$, respectively [44]

Given the result of the current experiment and the previous report regarding the enhanced solubility of non-polar compounds in a water phase by using Class II hydrophobin HFBII as an encapsulant $[34,35]$, it is proposed that the film created by HFBII around the volatile and lipophilic compounds in food products and medicines, not only reduces the escaping ratio of those compounds, but also prevents their oxidation.

Many studies used a mixture of peptides as a natural antioxidant, this is due to the fact that in most of cases, a sole peptide has a very small effect on oxidants. Thus, by use of several peptides with different structures or sequences, synergistic effects may occur. By mixing the peptides, however, the fundamental mechanism of antioxidant activity is masked and will remain unclear. It is i) easier, ii) safer, and iii) perhaps more cost effective to produce and purify a microbial antioxidant than to extract a mixture with potential of antioxidant activity from a seed or a plant, iv) also the legal approval of the application of a pure protein is more likely, and finally v) some proteins, in particular hydrophobins, possess several extracellular characteristics:

i) It is easier to produce antioxidants from a microbial source since the cultivation of microorganisms, i.e. producers of secondary metabolites, is a well-regulated and understood biotechnological production route.

ii) It is safer to produce proteins from a microbial source than extract from plants as, unfortunately, it is not always possible to identify all the fractions of the protein mixtures obtained from plants. There are sometimes allergens or toxic products as for instance, chitinase Ib and lipid transfer protein from Chestnut [45], profiling, lipid transfer protein, and $11 \mathrm{~S}$ globulin-like protein from Hazelnut [46], ochratoxin A (OTA) in liquorice products $[47,48,49]$, and aflatoxin $B_{1}$ in pistachio [50]. Thus complex analysis and a very sensitive method are required to ensure that the obtained product is safe. In the case of bioactive peptides from walnuts, tested in this research as a positive control for antioxidant activity, there is a risk of the presence of $2 \mathrm{~S}$ albumin which is an allergen [51]. This nut is also always exposed to the mycotoxins produced by different storage molds, for instance Aspergillus sp. 
which produce OTA [52]. Thus, it is possible to overcome the allergy effect of plant extracts through the development of new natural sources of antioxidants.

iii) Production of microbial antioxidants is potentially cheaper than getting antioxidants directly from plants. In the case of the production cost of antioxidant obtained from seeds or plants the following stages have to be considered: implanting, harvesting and post-harvesting processing of the plant, extraction, purification, as well as analysis of the safety of the extracted product. Normally after extraction of the antioxidant from the plants or the seeds they are no longer fit for consumption because the extraction process transforms the texture and the nutritional properties of the products. In the case of production of natural antioxidants by microorganisms, it is only required to describe a protocol for the growth of the microorganisms and releasing the product as well as a purification step. It is also possible to increase the yield of produced microbial metabolites by using recombinant microorganisms, improving the design of bioreactors and optimization of the fermentation conditions, through the application of biochemical engineering.

iv) It should be mentioned that for both cases, i.e. getting the antioxidant from plants or production by microorganisms, the use of final product needs to be authorized before industrial application. Of course, meeting these criteria is more difficult with a mixture of compounds, than a sole compound.

v) The additional advantage of using hydrophobin HFBII, as an alternative of other sources of antioxidants, is its extracellular structures and the special characteristics [53]. This protein possesses several functionalities in real products; it can lower the surface tension of the water due to its amphipathic nature [54], it creates highly stable foams in foods and beverages [55], it can be applied as a carrier of pharmaceuticals [56] and food ingredients [35], and has also recently been reported to possess anti-tumor activity [57].

\subsection{Computational modeling of HFBII and ABTS: Possible interactions}

Computational modeling using AutoDock was carried out to understand the possible mechanism of antioxidant activity of hydrophobin HFBII in the presence of an ABTS molecule. In the model HFBII was considered to be a dimer. This state was previously reported for the current working concentration $[58,59]$. The results showed that more than 
150 situations may occur when both HFBII dimer and ABTS are combined in an isolated box of the experiment. Nevertheless, the most probable situation with the lowest activation energy revealed that only few amino acids of HFBII are involved in the possible interactions. These include Threonine $_{16}$, Valine $_{18}$, Valine $_{24}$ from Chain A HFBII, and Asparagine 17, Valine $_{18}$, Leucine $_{19}$, Aspartic $\operatorname{acid}_{20}$, Lysine 49 from Chain B HFBII. More importantly, the result showed that $\operatorname{Leucin}_{19}$ may also create a hydrogen bond $(2.97 \AA$ ) to interact with ABTS (Fig. 4). Another interesting observation was the intention of the molecule ABTS to approach into the hydrophobic patch of HFBII, re-emphasizing this patch as an active site of HFBII.

\subsection{ACE-inhibitory of $\kappa$-HFBII}

Fig. 5. shows the ACE-inhibitory effects of different concentrations of hydrophobin HFBII in the range of $0.1-0.6 \mathrm{mg} / \mathrm{mL}$.

The obtained pure Class II hydrophobin HFBII showed a very small ACE-inhibitory effect in comparison with positive control, i.e. a mixture of bioactive peptides extracted from the Persian walnut. A concentration of $0.05 \mathrm{mg} / \mathrm{mL}$ of extract from the latter reduced ACE activity by $47 \pm 1 \%$. When using high concentrations of hydrophobin HFBII, the ACE activity started dropping. The decline is significant from HFBII concentrations of $0.5 \mathrm{mg} / \mathrm{mL}$ and upwards. This point is approximately 12 times higher than the $\mathrm{CMC}$ reported for HFBII (i.e. $0.041 \mathrm{mg} / \mathrm{mL}$ ). In comparison with the Persian walnut, HFBII is a weak ACE-inhibitor. Nevertheless, since hydrophobin is a natural non-toxic product with a straightforward procedure of production, showing also antioxidant activity and other functionalities, it is proposed to combine HFBII with drugs, like angiotensin receptor blockers and applying it to treat a broad variety of disorders.

As the structure of $\kappa$-HFBII has been widely studied, it is easy to postulate the exact mechanism of the action of this protein on ACE rather than any peptide mixtures extracted from the plants. The ACE-inhibitory effects of HFBII may due to the presence of a significant hydrophobic patch, which enhances binding of HFBII to the active site of ACE. The low ACE-inhibitory of Class II hydrophobins may correspond to the poor content of Prolin amino acid at carboxyl terminal and its large size in comparison with the peptides. 
The use of the Class II hydrophobin HFBII as a coating agent of different molecules has been previously reported. In our previous work, we examined the retention time of ocimene, a nonpolar volatile compound from the hops, in a water phase containing hydrophobin HFBII. Our results clearly showed that HFBII postponed the escape of ocimene molecules from the water phase. In that research we concluded that due to the hydrophobicity of ocimene, HFBII may cover the ocimene via the hydrophobic patches, and prevents its micellization and volatility of the molecules. Our new findings in the current study claims that the conclusion from the previous work was incomplete due to the fact that the antioxidant activity of hydrophobin may also prevent the possible oxidation phenomenon, and this is probably another reason for maintaining the ocimene in the system for a longer period. Here, we showed that HFBII can play a role as an antioxidant and reduce the presence of free radicals of ABTS in the environment. We used $\mathrm{ABTS}^{\circ}$ to study this effect, but it is important to note that HFBII does not coat ABTS ${ }^{\circ}$. Actually, the HFBII dimer interacts with ABTS through specific amino acids residues (i.e. Threonine ${ }_{16}$, Valine $_{18}$, Valine $_{24}$ from Chain A HFBII, and Asparagine ${ }_{17}$, Valine $_{18}$, Leucine 19 , Aspartic acid $_{20}$, Lysine $_{49}$ from Chain B HFBII), modeled by AutoDock. In this study, we also demonstrated that this protein possesses ACE-inhibitory effects at high HFBII concentrations. Thus, by using Class II hydrophobin HFBII as an encapsulant, first of all, the elastic skin formed retards the escape of lipophilic volatile compounds. Secondly, it prevents harmful deterioration processes e.g. oxidation. The fact that the antioxidants extracted from natural plants or seeds may be allergens encourages biotechnologists to characterize novel microbial antioxidants. We showed that Class II hydrophobin HFBII is a good candidate in this case and that this functionality corresponds significantly to the hydrophobic patch of HFBII. It seems that in the near future, bioproduction of antioxidants and ACE-inhibitors by native microorganisms will gain wider attention from the healthcare industry.

\section{Acknowledgment}

The authors would like to thank the Iran National Elites Foundation (INEF)-International Department and Hydrophobin Chair II for supporting this project. The support of UNESCO Chair on Interdisciplinary Research in Diabetes is also acknowledged. 
[1] E. Choe, D.B. Min, Mechanisms of Antioxidants in the Oxidation of Foods. Compr. Rev. Food Sci. F. 8 (2009) 345-358.

[2] H.N. Siti, Y. Kamisah, J.K.K.H. Musa, A. Abdullah, A. Al-Haiqi, Determination of DPPH free radical scavenging activity: Application of artificial neural networks, Food Chem. 194 (2016) 705-711.

[3] H.N. Siti, Y. Kamisah, J. Kamsiah, The role of oxidative stress, antioxidants and vascular inflammation in cardiovascular disease (a review), Vasc. Pharmacol. 71 (2015) 40-56.

[4] X-T. Luo, C-M. Wang, Y. Liu, Z-G. Huang, New multifunctional melatonin-derived benzylpyridinium bromides with potent cholinergic, antioxidant, and neuroprotective properties as innovative drugs for Alzheimer's disease. Eur. J. Med. Chem. 103 (2015) 302311.

[5] K. Masisi, T. Beta, M.H. Moghadasian, Antioxidant properties of diverse cereal grains: A review on in vitro and in vivo studies, Food Chem. 196 (2016) 90-97.

[6] M. Mirzaei, S. Mirdamadi, M.R. Ehsani, M. Aminlari, E. Hosseini, Purification and identification of antioxidant and ACE-inhibitory peptide from Saccharomyces cerevisiae protein hydrolysate, J. Funct. Foods 19 (2015) 259-268.

[7] P. Ambigaipalan, A.S. Al-Khalifa, F. Shahidi, Antioxidant and angiotensin I converting enzyme (ACE) inhibitory activities of date seed protein hydrolysates prepared using Alcalase, Flavourzyme and Thermolysin. J. Funct. Foods 18 (2015) 1125-1137.

[8] M. Rahimi, S.M. Ghaffari, M. Salami, S.J. Mousavy, A. Niasari-Naslaji, R. Jahanbani, S. Yousefinejad, M. Khalesi, A.A. Moosavi-Movahedi, ACE- inhibitory and radical scavenging activities of bioactive peptides obtained from camel milk casein hydrolysis with proteinase $\mathrm{K}$. Dairy Sci. Technol. (2016) (In Press) DOI 10.1007/s13594-016-0283-4

[9] B. Tom, A. Dendorfer, A.H.J. Danser, Bradykinin, angiotensin-(1-7), and ACEinhibitors: how do they interact? Int. J. Biochem. Cell Biol. 35 (6) (2003) 792-801. human somatic ACE, Eur. J. Pharmacol. 577 (2007) 1-6. 
390

391

392

393

394

395

396

397

398

399

400

401

402

403

404

405

406

407

408

409

410

411

412

413

414

415

416

417

418

[11] M. Prabhu, S. Palaian, A. Malhotra, P. Ravishankar, D. Bista, R. Almeida, P. Mishra, Therapeutic dimensions of ACE-inhibitors - A review of literature and clinical trials, Kathmandu Univ. Med. J. 3 (2005) 296-304.

[12] Baram. M, A. Kommuri, S.A. Sellers, J.R. Cohn, Grand Rounds Review: ACEinhibitor-Induced Angioedema, J. Allergy Clin. Immunol. Pract. 1 (2013) 442-445.

[13] H. Han, Blood pressure medications: ACE-I/ARB and chronic kidney disease, J. Renal Nutr. 23 (2013) 105-107.

[14] S.K. Kota, L.K. Meher, S. Jammula, S.K. Kota, K.D. Modi, ACE-inhibitors or ARBs for diabetic nephropathy: The unrelenting debate. Diabetes Metab. Syndr. 6 (2012) 215-217.

[15] C. Gupta, D. Prakash, S. Gupta, Functional foods enhanced with microbial antioxidants, Academic Journal of Nutrition 2 (2013) 10-18.

[16] S.C. Jeong, J.H. Kim, N-M. Kim, J.S. Lee, Production of antihypertensive angiotensin Iconverting enzyme inhibitor from Malassezia pachydermatis G-14, Mycobiology 33 (2005) 142-146.

[17] R. Prasanna, B. Nandhini, B.V. praveesh, J. Angayarkanni, M. Palaniswamy, Novel angiotensin converting enzyme inhibitor from Aspergillus sp. by solid state fermentation, Int. J. Pharm. Pharm. Sci. 4 (2012) 371-377.

[18] C. Gupta, D. Prakash, S. Gupta, Functional foods enhanced with microbial antioxidants, Academic Journal of Nutrition 2 (2013) 10-18.

[19] F. Sedaghat, M. Yousefzadi, H. Toiserkani, S. Najafipour, Chitin from Penaeus merguiensis via microbial fermentation processing and antioxidant activity. Int. J. Biol. Macromol. 82 (2016) 279-283.

[20] T. Aoyama, Y. Nakakita, M. Nakagawa, H. Sakai, Screening for antioxidants of microbiology origin, Agricul. Biol. Chem. 46 (1982) 2369-2371.

[21] M.B. Linder, G.R. Szilvay, T. Nakari-Setälä, M.E. Penttila, Hydrophobins: the proteinamphiphiles of filamentous fungi, FEMS Microbiol. Rev. 29 (2005) 877-896.

[22] M. Khalesi, S. Deckers, K. Gebruers, L. Vissers, H. Verachtert, G. Derdelinckx, Hydrophobins: Exceptional proteins for many applications in brewery environment and other bio-industries, Cerevisia 37 (2012) 3-9. 
[23] Linder M.B., Hydrophobins: Proteins that self assemble at interfaces, Curr. Opin. 420 Colloid Interface Sci. 14 (2009) 356-363.

421 [24] M. Khalesi, N. Mandelings, Z. Shokribousjein, D. Riveros-Galan, H. Verachtert, K. 422 Gebruers, F. Delvigne, I. Vankelecom, G. Derdelinckx, Biophysical characterisation of 423 hydrophobin enriched foamate, Cerevisia 38 (2014) 129-134.

[25] E.S. Basheva, P.A. Kralchevsky, N.C. Christov, K.D. Danov, S.D. Stoyanov, T.B.J. Blijdenstein, H-J. Kim, E.G. Pelan, A. Lips, Unique properties of bubbles and foam films stabilized by HFBII hydrophobin, Langmuir 27 (2011) 2382-2392.

[26] R.D. Stanimirova, T.D. Gurkov, P.A. Kralchevsky, K.T. Balashev, S.D. Stoyanov, E.G. Pelan, Surface pressure and elasticity of hydrophobin HFBII layers on the air-water interface: Rheology versus structure detected by AFM imaging, Langmuir 29 (2013) 60536067.

[27] K. Scholtmeijer, J.G.H. Wessels, H.A.B. Wösten, Fungal hydrophobins in medical and technical applications, Appl. Microbiol. Biot. 56 (2001) 1-8.

[28] A.R. Cox, F. Cagnolm, A.B. Russell, M.J. Izzard, Surface properties of class II hydrophobins from Trichoderma reesei and influence on bubble stability, Langmuir 23 435 (2007) 7995-8002.

[29] A.R. Cox, D.L. Aldred, A.B. Russell, Exceptional stability of food foams using class II hydrophobin HFBII, Food Hydrocolloid. 23 (2009) 366-376.

[30] F.L. Tchuenbou-Magaia, I.T. Norton, P.W. Cox, Hydrophobins stabilised air-filled 439 emulsions for the food industry, Food Hydrocolloid. 23 (2009) 1877-1885.

440 [31] S. Deckers, L. Vissers, K. Gebruers, Z. Shokribousjein, M. Khalesi, D. Riveros441 Galan, C. Schönberger, H. Verachtert, H. Neven, J. Delcour, C. Michiels, V. Ilberg, G. Derdelinckx, J. Titze, J. Martens, Doubly modified Carlsberg test combined with dynamic light scattering allows prediction of the primary gushing potential of harvested barley and malt, Cerevisia 37 (2012) 77-81.

445 [32] S. Deckers, L. Vissers, M. Khalesi, Z. Shokribousjein, H. Verachtert, K. Gebruers, X. 446 Pirlot, J. Rock, V. Illberg, J. Titze, H. Neven, G. Derdelinckx, Thermodynamic view of 447 primary gushing, J. Am. Soc. Brew Chem. 71 (2013) 149-152. 

model of primary gushing: From nanobubble formation until liquid expulsion. J. Am. Soc. Brew. Chem. 73 (2015) 343-346.

451

452

453

454

455

456

457

458

459

460

461

462

463

464

465

466

467

468

469

470

471

472

473

474

475

476

[34] H.K. Valo, P.H. Laaksonen, L.J. Peltonen, M.B. Linder, J.T. Hirvonen, T.J. Laaksonen, Multifunctional hydrophobin: Toward functional coatings for drug nanoparticles, ACS Nano. 4 (2010) 1750-1758.

[35] M. Khalesi, N. Mandelings, B. Herrera-Malaver, D. Riveros-Galan, K. Gebruers, G. Derdelinckx, Improvement of the retention of ocimene in water phase using Class II hydrophobin HFBII, Flavour Fragr. J. 30 (2015) 451-458.

[36] M.J. Bailey, S. Askolin, N. Hörhammer, M. Tenkanen, M. Linder, M. Penttilä, N. Setälä, Process technological effects of deletion and amplification of hydrophobins I and II in transformants of Trichoderma reesei, Appl. Microbiol. Biot. 58 (2002) 721-727.

[37] S. Deckers, T. Venken, M. Khalesi, K. Gebruers, G. Baggerman, Y. Lorgouilloux, Z. Shokribousjein, V. Ilberg, C. Schönberger, J. Titze, H. Verachtert, C. Michiels, H. Neven, J. Delcour, J. Martens, G. Derdelinckx, M. De Maeyer, Combined modeling and biophysical characterisation of $\mathrm{CO}_{2}$ interaction with class II hydrophobins: New insight into the mechanism underpinning primary gushing, J. Am. Soc. Brew. Chem. 70 (2012) 249-256.

[38] M. Khalesi, Q. Zune, S. Telek, D. Riveros-Galan, H. Verachtert, D. Toye, K. Gebruers, G. Derdelinckx, F. Delvigne, Fungal biofilm reactor improves the productivity of hydrophobin HFBII, Biochem. Eng. J. 88 (2014) 171-178.

[39] M. Khalesi, K. Gebruers, G. Derdelinckx, Recent advances in fungal hydrophobin towards using in industry, Protein J. 34 (2015) 243-255.

[40] R. Re, N. Pellegrini, A. Proteggente, A. Pannala, M. Yang, C. Rice-Evans, Antioxidant activity applying an improved ABTS radical cation decolorization assay. Free Radical Biol. Med. 26 (1999) 1231-1237.

[41] M. Salami, A.A. Moosavi-Movahedi, M.R. Ehsani, R. Yousefi, T. Haertlé, J.M. Chobert, S.H. Razavi, R. Henrich, S. Balalaie, S.A. Ebadi, S. Pourtakdoost, A. Niasari-Naslaji, Improvement of the antimicrobial and antioxidant activities of camel and bovine whey proteins by limited proteolysis, J. Agric. Food Chem. 58 (2010) 3297-3302. 
[42] V. Vermeirssen, J. Van Camp, W. Verstraete, Optimisation and validation of an angiotensin-converting enzyme inhibition assay for the screening of bioactive peptides, $\mathrm{J}$ Biochem Bioph Meth. 51 (2002) 75-87.

[43] F.L. Hsu, Y.H. Lin, M.H. Lee, C.L. Lin, W.C. Hou, Both dioscorin, the tuber storage protein of yam and its peptic hydrolysates exhibited angiotensin converting enzyme inhibitory activities, J Agric. Food Chem. 50 (2002) 6109-6113.

[44] A. Durak, B. Baraniak, A. Jakubczyk, M. Swieca, Biologically active peptides obtained by enzymatic hydrolysis of Adzuki bean seeds. Food Chem. 141 (2013) 2177-2183.

[45] F.J. Garcia-Selles, A. Diaz-Perales, S.R. Monge, M. Alcantara, M. Lombardero, D. Barber, G. Salcedo, M. Fernandez-Rivas, Patterns of reactivity of lipid transfer proteins of plant foods and Artemisia pollen: an in vivo study, Int. Arch. Allergy Immunol. 128 (2002) $115-122$.

[46] K.H. Roux, S.S. Teuber, S.K. Sathe, Tree nut allergens, Int. Arch. Allergy Immunol. 131 (2003) 234-244.

[47] M. Khalesi, M. Sheikh-Zeinoddin, M. Tabrizchi, Determination of ochratoxin A in licorice root using inverse ion mobility spectrometry, Talanta 83 (2011) 988-993.

[48] M. Khalesi, N. Khatib, The effects of different ecophysiological factors on ochratoxin A production, Environ. Toxicol. Pharmacol. 32 (2011) 113-121.

[49] M. Khalesi, Ochratoxin A in liquorice products - a review, Food Addit. Contam. A 32 (2015) 2086-2092.

[50] M. Georgiadou, Chr. Gardeli, M. Komaitis, D.I. Tsitsigiannis, E.J. Paplomatas, K. Sotirakoglou, S. Yanniotis. Volatile profiles of healthy and aflatoxin contaminated pistachios. Food Res. Int. 74 (2015) 89-96.

[51] S.S. Teuber, A.M. Dandekar, W.R. Peterson, C.L. Sellers, Cloning and sequencing of a gene encoding a $2 \mathrm{~S}$ albumin seed storage protein precursor from English walnut (Juglans regia) - a food allergen, J. Allergy Clin. Immunol. 101 (1998) 807-814.

[52] M. Khalesi, M. Tabrizchi, M. Sheikh-Zeinoddin, The effects of temperature and relative humidity on ochratoxin A formation in fresh liquorice root. Food Addit. Contam. A 30 (2013) 339-344. 
[53] D. Riveros., Z. Shokribousjein, P. Losada-Pérez, M. Khalesi, K. Cordova, C. Michiels,

507 J.A. Delcour, H. Verachtert, P. Wagner and G. Derdelinckx, Comparison of structure, 508 sequence, physical interactions and its effects on primary gushing among several Class II 509 hydrophobins. Brew.Sci. 68 (2015) 38-45.

510 [54] M. Khalesi, K. Gebruers, D. Riveros-Galan, S. Deckers, A.A. Moosavi-Movahedi, H. 511 Verachtert, G. Derdelinckx. Hydrophobin purification based on the theory of $\mathrm{CO}_{2}$ nanobubbles. J. Liq. Chromatogr. R. T. 39 (2016) 111-118.

513 [55] M. Khalesi, T Venken, S. Deckers, J Winterburn, Z. Shokribousjein, K. Gebruers, H. 514 Verachtert, J. Delcour, P. Martin, G. Derdelinckx. A novel method for hydrophobin 515 extraction using $\mathrm{CO}_{2}$ foam fractionation system. Ind. Crop. Prod. 43 (2013) 372-377.

516 [56] M.P. Sarparanta, L.M. Bimbo, E.M. Mäkilä, J.J. Salonen, P.H. Laaksonen, A.M.K. 517 Helariutta, M.B. Linder, J.T. Hirvonen, T.J. Laaksonen, H.A. Santos, A.J. Airaksinen, The 518 mucoadhesive and gastroretentive properties of hydrophobin-coated porous silicon 519 nanoparticle oral drug delivery systems. Biomaterials 33 (2012) 3353-3362.

520 [57] M.H.J. Akanbi, E. Post, S.M. van Putten, L. de Vries, J. Smisterova, A.H. Meter521 Arkema, H.A.B. Wösten, R. Rink, K. Scholtmeijer, The antitumor activity of hydrophobin 522 SC3, a fungal protein. Appl. Microbiol. Biotechnol. 97 (2013) 4385-4392.

523 [58] E.S. Basheva, P.A. Kralchevsky, K.D. Danov, S.D. Stoyanov, T.B.J. Blijdenstein, E.G. 524 Pelan, A. Lips, Self-assembled bilayers from the protein HFBII hydrophobin: Nature of the 525 adhesion energy. Langmuir 27 (2011) 4481-4488.

526 [59] J. Burke, A. Cox, J. Petkov, B.S. Murray. Interfacial rheology and stability of air bubbles 527 stabilized by mixtures of hydrophobin and $\beta$-casein. Food Hydrocolloid. 34 (2014) 119-127. 
Table and Table Caption.

\section{Table 1}

Characteristics of the SOURCE 30RPC polymer based matrix and the purification condition.

Matrix

Bead form

Particle size

Dynamic capacity

Operating $\mathrm{pH}$

Operating temperature
Poly(styrene/divinyl benzene)

Rigid, spherical, porous, monodisperse

$30 \mu \mathrm{m}$

$14 \mathrm{mg} \mathrm{BSA} / \mathrm{mL}$

4.7

$25^{\circ} \mathrm{C}$ 
Figures and Figure captions.

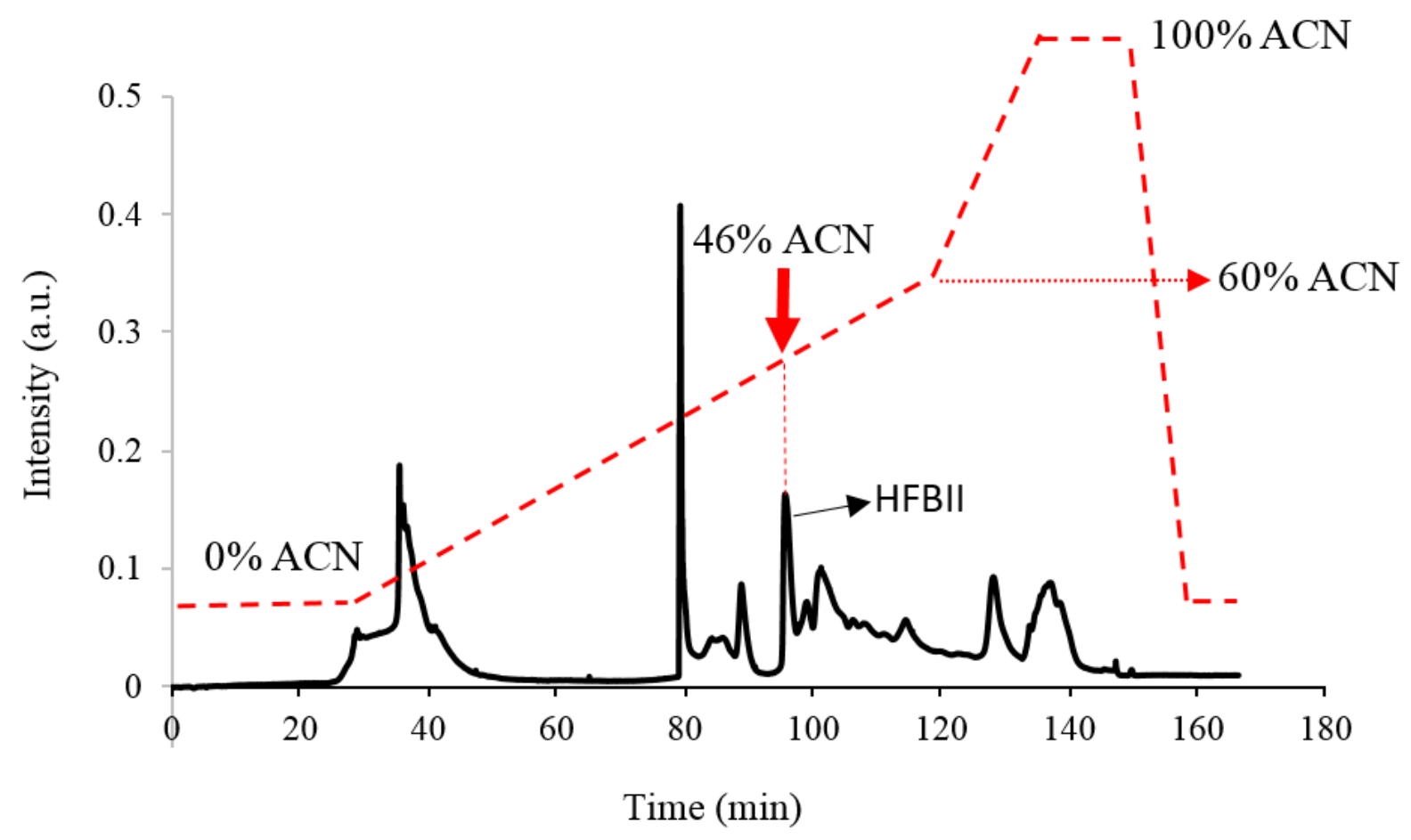

Fig. 1. An example of chromatograms for the culture medium containing hydrophobin HFBII resulting from fermentation of $T$. reesei after purification by SOURCE 30RPC column, recorded at a wavelength of $214 \mathrm{~nm}$. The dashed line shows the ACN\% gradient. HFBII was eluted with solvent containing $46 \% \mathrm{ACN}$ and $0.1 \%$ TFA. 


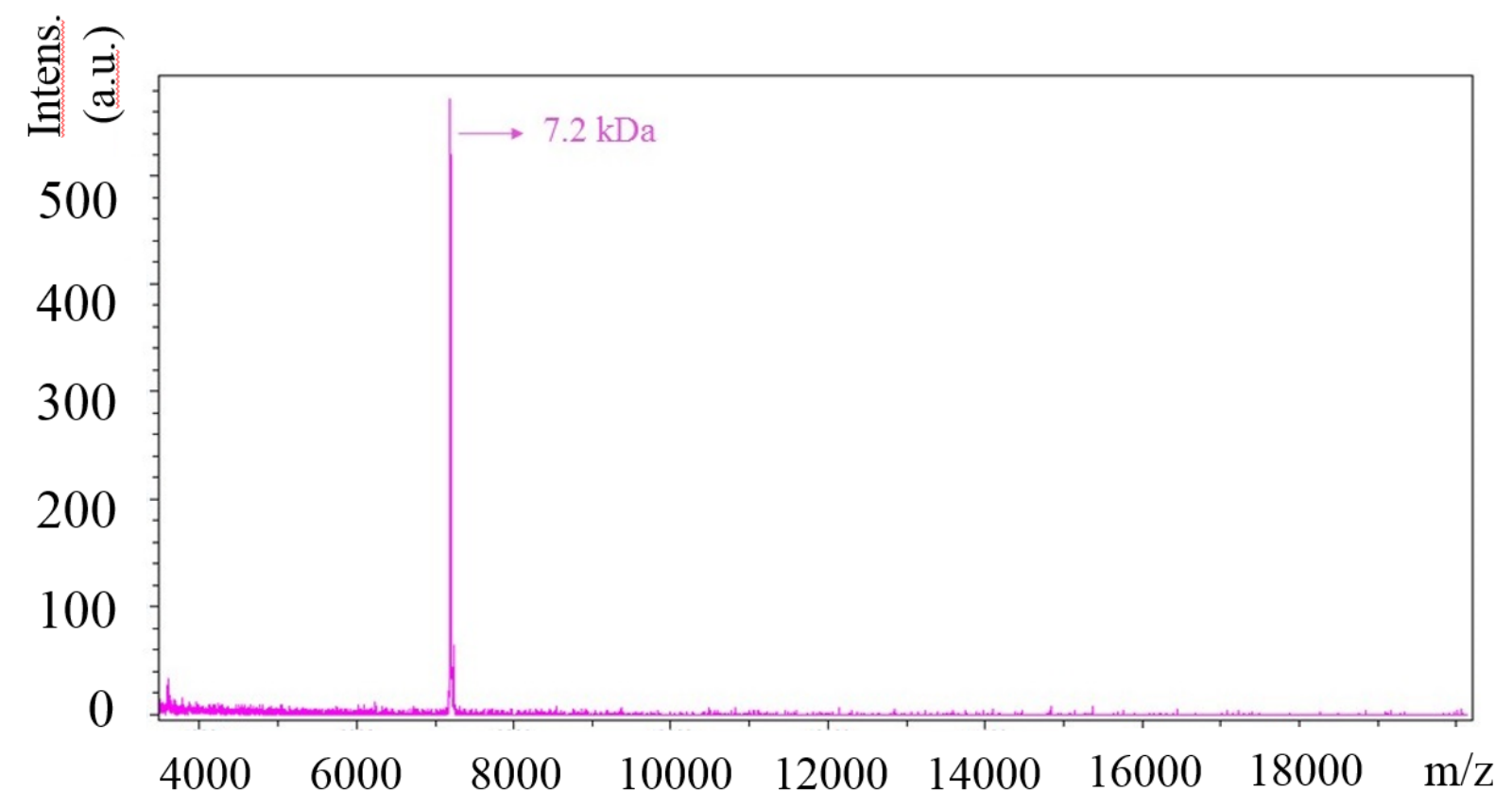

Fig. 2. MALDI-TOF spectrum of $\kappa$-HFBII obtained from T. reesei after the purification step using chromatography. 


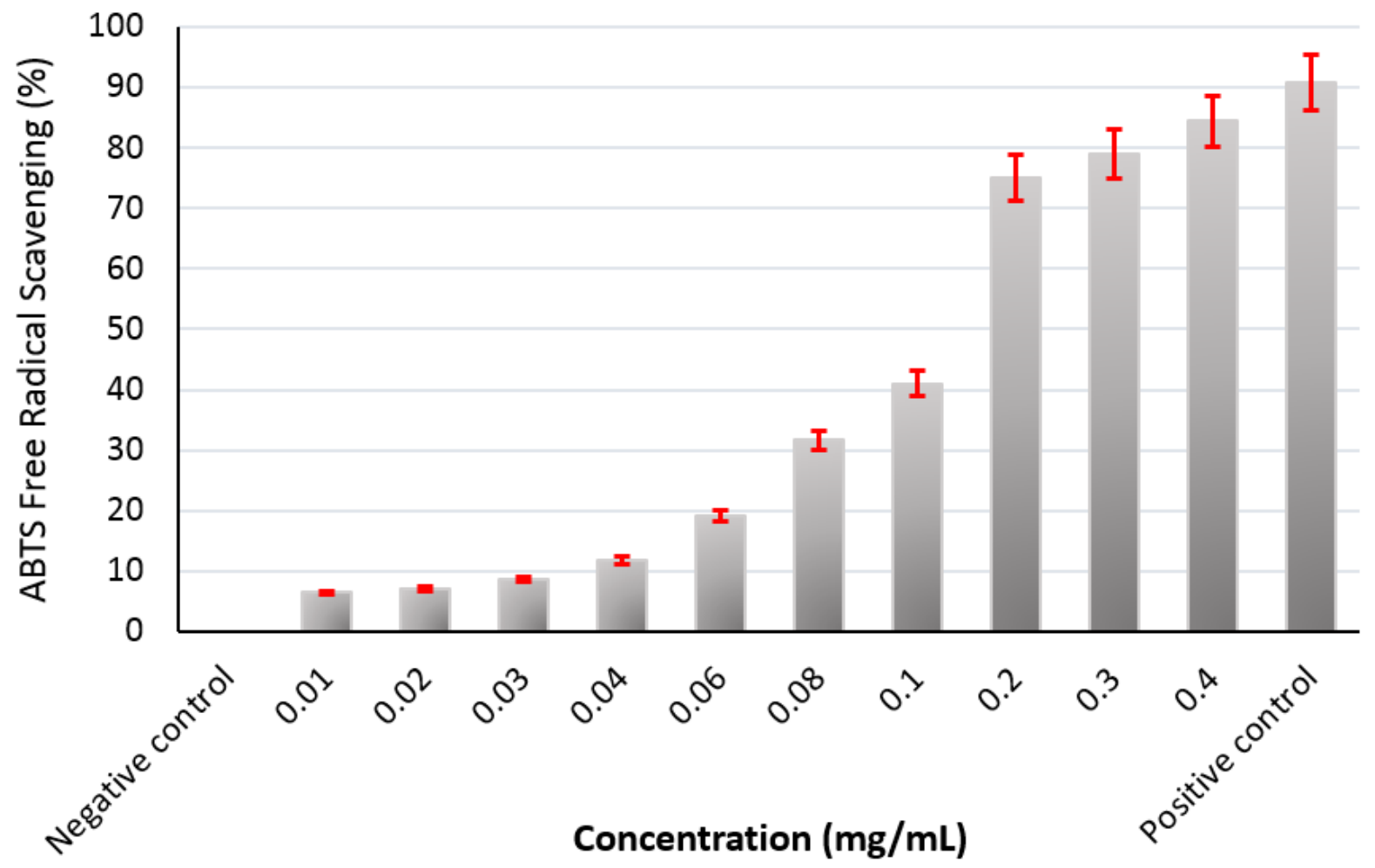

Fig. 3. Radical scavenging properties of Class II hydrophobin $\kappa$-HFBII from wild strain T. reesei. The negative control was considered to be the $\mathrm{ABTS}^{\circ+}$ solution without addition of $\kappa$-HFBII. The positive control was considered to be a mixture of bioactive peptides extracted from the Persian walnut with a concentration of $0.05 \mathrm{mg} / \mathrm{mL}$. 


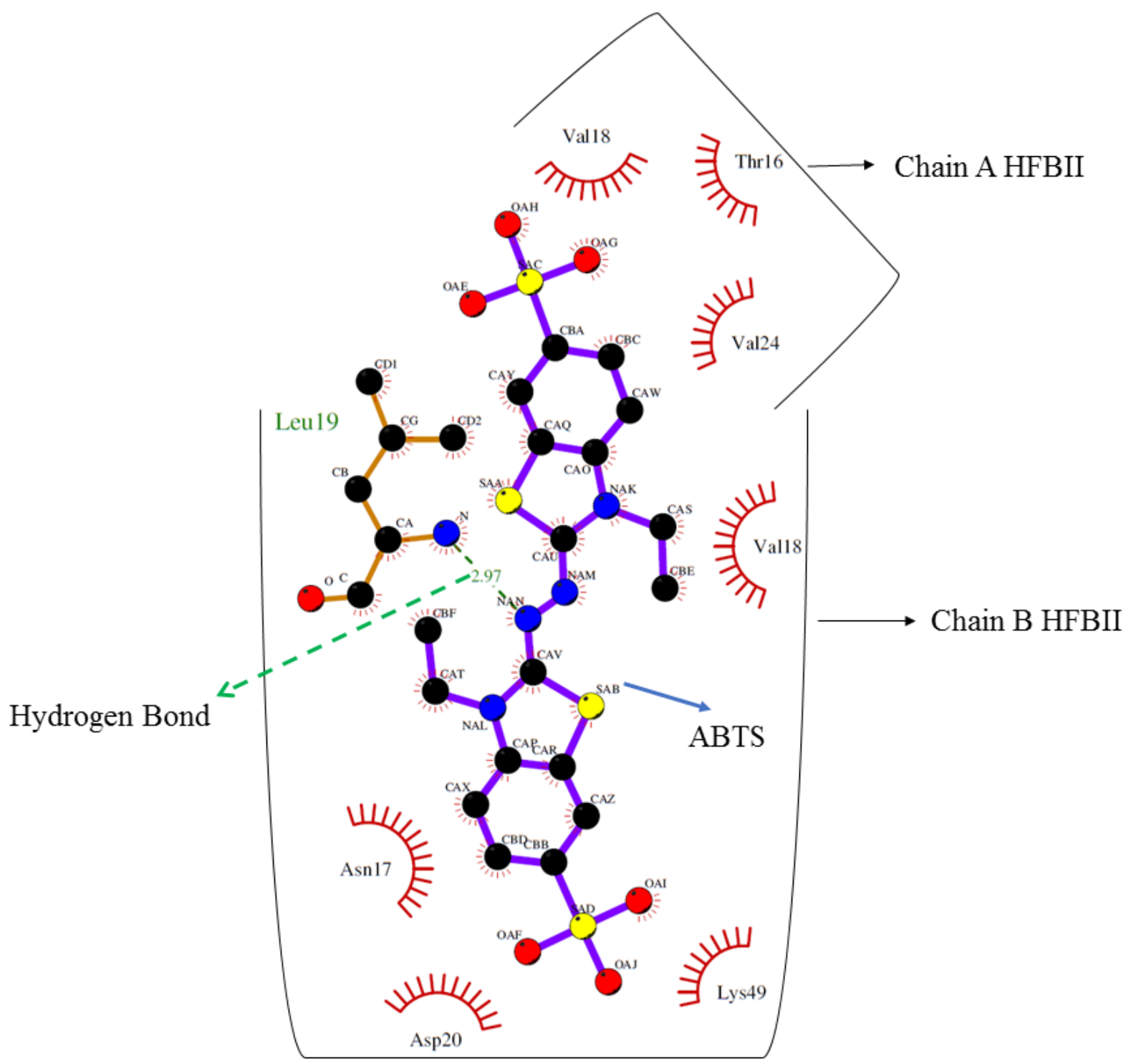

Fig. 4. Two dimensional image presentation of peripheral site residues of HFBII (dimer) and the molecule of ABTS. The most probable interacting residues of HFBII include Threonine ${ }_{16}$, Valine ${ }_{18}$, Valine $_{24}$ from Chain A HFBII, and Asparagine 17 , Valine ${ }_{18}$, Leucine $_{19}$, Aspartic acid 20 , Lysine 49 from Chain B HFBII. A hydrogen bond between Leucine ${ }_{19}$ from chain B and ABTS is occurred. 


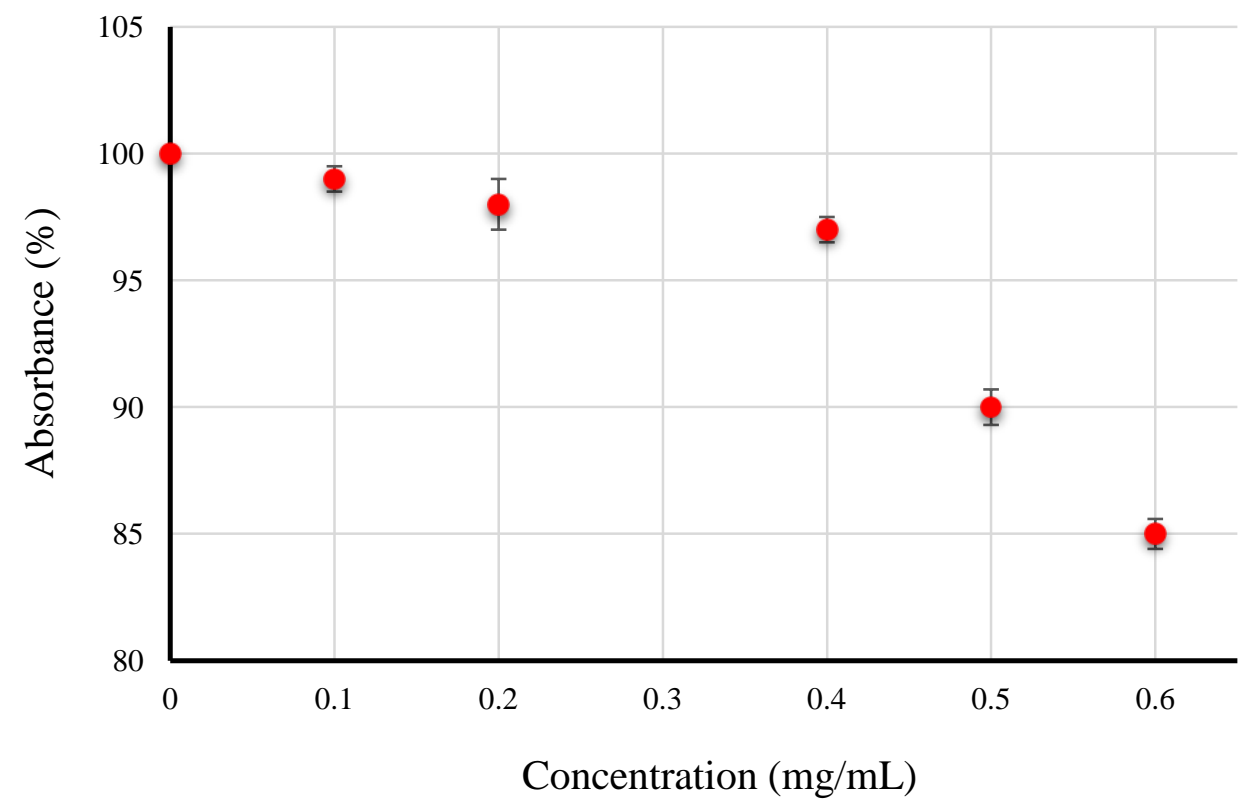

Fig. 5. ACE inhibitory of pure Class II hydrophobin HFBII produced by wild strain T. reesei. 